\title{
Trenching Dissent: Women's Collective Action Frame in the Uprising*
}

RESPONDENT: ... the fact that many Egyptians do not know that the nationalist leader Makram Ebeid is Coptic is not a sign of our national unity, it is primarily because our history textbooks do not mention his religion; that is why young generations did not know he is Coptic!

INTERVIEWER: Well, why do you think his religion is not mentioned in history textbooks?

RESPONDENT: I do not know. I have just always felt that the national unity talk is sometimes real but also and for sure partly orchestrated, particularly at times of contentions and political struggles.

INTERVIEWER: Hmmm.

RESPONDENT: We think that a strong social fabric needs to be colorless; this myth is deeply ingrained in our collective memory of nationalist struggles, and thus at times of political struggles we all feel a duty to perform within its contours. ${ }^{1}$

The mainstream framing of modern and historical political struggles in Egypt is often constructed around the discourse of national unity. Political struggles are documented as a story of unity and solidarity where religious, class, and gender differences meant few if any signs of distinction among participants. The example of the Coptic nationalist leader Makram Ebeid, a key figure in the country's anti-colonial struggles in the 1920s, is often cited as one example of this national unity. This is because, as the story goes, many Egyptians are not aware of his religion.

However, as the above quote suggests, his religion is deliberately omitted from history and collective memory in Egypt, and this

* An abridged version of this chapter was presented under the title "Trenching Dissent: Women's Collective Action Frame in the Uprising" at the American Political Science Association (APSA) MENA Workshop, Tunisia, June 7-14, 2014.

${ }^{1}$ Interviewee 31. Author's interview, Cairo, Egypt, July 2013. 
omission contributes to constructing a "colorless social fabric." The success of political struggles is believed to be contingent on staging national unity based on a colorless ${ }^{2}$ social fabric in which differences are not endorsed but rather omitted. This myth is especially influential during political struggles in which participants feel a duty to stage this performance of unity and solidarity and thus communicate power to their opponents. My aim in this chapter is to demonstrate that women's framing of their participation in the 2011 uprising must be read against this broader public discourse, a discourse that champions "colorless" framing of collective action.

Erving Goffman, in his classic book The Presentation of Self in Everyday Life (1959), examined this performative aspect of social interactions in great detail. In his book, Goffman described the world as a "stage" on which all social interactions are carried out by "staged people." They use the main stage to play roles, perform routines, and confront others while wearing masks. For critical anthropologist Victor Turner, the dramaturgical phase begins when people "exert their wills and unleash their emotions to achieve goals which until that time have remained hidden or may even have been unconscious"(1979: 65). These crises are inherently dramatic as participants deliberately perform and show their actions to others; actions thus assume a "performed-for-an-audience" aspect (Turner 1979: 63).

Appropriating this perspective, Robert D. Benford and Scott A. Hunt depict social movements as "dramas in which protagonists and antagonists compete to affect audiences' interpretations of power relations in a variety of domains" (1992: 38). In these dramas, participants attempt to replace "a dominant belief system that legitimizes the status quo with an alternative mobilizing belief system that supports collective action for change" (Gamson, Fireman, and Rytina 1982: 15). Participants in social movements are thus not merely influenced by the structure. Rather, they cluster around "collective action frames" (Benford 1993, 1997; Snow and Benford 1988, 1992; Snow, Soule, and Kriesi 2004; Snow, Worden, and Benford 1986).

2 At times of political struggle, the social fabric, it can be argued, appears colorful in mien yet colorless in content. That is, participants showcase that they come from different walks of life and thus the social fabric appears colorful, but the discourse among participants is often colorless in the sense that the unity of demands is highly emphasized. 
At the most basic level, a frame identifies a problem that is social or political in nature, the parties responsible for causing it, and the possible solutions they offer (Johnston and Noakes 2005: 2; see also Gamson 1975; Snow and Benford 1988, 1992). Frames in the "theatre of contention" redefine a status quo that was perceived as "unfortunate but perhaps tolerable" to "unjust and immoral" (Tarrow 1998: 132) and thus mobilize participants to join repertoires of contention. This symbolic politics of social movements is, however, paradoxical (Snow and Benford 1992; Tarrow 2012).

The major dilemma of constructing collective action frames is to mediate between inherited symbols that are "familiar" but lead to "passivity" and new ones that are "electrifying" but may be too "unfamiliar" to lead to action (Tarrow 1998: 107). In mitigating this tension, collective action frames in social movements are woven from a blend of "inherited and invented fibres" to garner support and legitimacy for collective action (Tarrow 1993: 118; see also Snow and Benford 1988). Frames are thus culturally and politically embedded and are the outcome of social interactions broadly as well as the shifting opportunities and constraints at the time of contention.

This chapter focuses on women's collective action frame in the social drama of the 2011 Egyptian uprising. I approach women's collective action frame as not simply impermeable to external influence but as a response to the inherited cultural materials and historical framings of political struggles. The analysis offered in this chapter highlights some of the factors intrinsic to women's framing that have contributed to ensuring that women's collective action frames resonate with bystanders, allies, members of the public, and the media. The resonance of women's collective action frame, I highlight, was necessary to facilitate and legitimate their participation in collective action; however, it arguably contributed in part to limiting their rights in the post-uprising period.

In carrying out this analysis, I adopt a threefold approach. In the first section, I interrogate women's collective action frame to elucidate its intrinsic features. These features, I demonstrate, have provided women's collective action frames with the necessary credibility and resonance. Building upon frame analysis, in the second section I highlight the mainstream framing of women's political participation in Egypt. Frame analysis considers the effect of history, politics, and culture on the framing of participation in collective action. I build upon frame 
analysis to situate women's collective action frame during the uprising within the mainstream historical framing of political struggles and women's activism in Egypt. This framing, I argue, temporally concealed differences and inequalities that had traditionally obscured women's participation in politics yet limited their rights in the period after the uprising. From a gender perspective, the absence of women-centered demands implies the absence of conceptual spaces for women. In these spaces, feminist organizations, unions, and political parties articulate gender concerns and build networks and consciousness-raising groups that could eventually turn into a women's movement.

By offering a gender analysis of these early interactions, the chapter contributes to explaining the nature and implications of their gender dynamics. It recovers women's voices in the writing of history and opens up new ways of understanding the Egyptian uprising.

\section{Women's Collective Action Frame: The Citizen Frame}

Collective action frames emphasize subjective and symbolic aspects of social movements. In an important series of papers, sociologist David Snow and his collaborators build upon Goffman's (1974) concept of framing, arguing that collective action frames construct meaning for action. In Snow and Benford's words, a frame is an "interpretive schemata" that simplifies and condenses "the world out there by selectively punctuating and encoding objects, situations, events, experiences, and sequences of actions within one's present or past environment" (1992: 137). At times of collective action, the frame defines the motivations, grievances, and demands of the movement's members as well as their identity (Gamson 1975; Givan et al. 2010; Snow and Benford 1988, 1992).

The citizen frame is commonly deemed as the collective action frame adopted by different groups including women during the 2011 uprising in Egypt. When asked why they participated in the uprising, all female protestors and activists - interviewed by the researcher during 2012-2014 - framed their participation on the basis of their citizenship. During the 2011 uprising, women voiced basic citizenship demands and did not include gender-specific demands (see Ghonim 2012; Morsi 2014; Taher 2012, to cite a few). These basic citizenship demands coalesced around justice, freedom, and dignity. They demanded the fall of the regime and the prosecution of former 
president Husnī Mubarak and his family. Another demand called for Huriyya (freedom): freedom to participate fully in political life, to vote in free and fair elections, and to express their views and opinions without censorship or fear of persecution. ${ }^{3}$ A third demand was karama (dignity) and the end of police abuse, torture, and humiliation.

By adopting the citizen frame, several female protestors stress, the movement at large was able to secure wide support ${ }^{4}$ and encourage greater mobilization. 5 This is because the frame tapped deeprooted and widely shared grievances in its diagnostic framing of the problems. The diagnostic nature of some frames, James Scott (1992: 224) has argued, explains how a "revolt spreads like 'wildfire' looking like a very organized, coordinated uprising, when in fact, it was not." As thousands came out to protest against the dominant communist party in Czechoslovakia, Vaclav Havel emphasized the significance of their form of sporadic organization, its energy, and spark. In a question underscoring the significance of their organization, he asked:

Where did young people who had never known another system get their longing for truth, their love of freedom, their political imagination, their civic courage and civic responsibility? How did their parents, precisely the generation thought to have been lost, join them? How is it possible that so many people immediately understood what to do and that none of them needed any advice or instructions? (Havel 1990)

In the case of Egypt, this is explained in part by the adoption of the citizen frame by the different groups who participated in the 2011 collective action. The frame created what Tilly (1997: 133) calls "lineaments of durable connection." That is, the citizen frame became the major means through which different and diverse protestors, both men and women, religious and secular, built solidarity, expressed unity, demonstrated their challenges and sought external support (Al-Aswany 2012; El-Nagar and Abo-Dawood 2012; Amin 2012; Korany and El-Mahdai 2012; Louër 2011). Protestors often pointed out how different groups adopted the citizen frame regardless of their affiliation and their religious, political, and social leanings. During

\footnotetext{
${ }^{3}$ Interviewee 61. Author's interview, Cairo, Egypt, October 2014.

${ }^{4}$ Interviewee 1. Author's interview, Cairo, Egypt, July 2012.

${ }^{5}$ Interviewee 12. Author's interview, Cairo, Egypt, July 2012.
} 
the 18-day uprising, members of the Muslim Brotherhood, a protestor rightly emphasized, did not voice any "demands specific to the [Muslim Brotherhood] organization." "They did not, for example, demand lifting the ban on their political representation - a ban that has been in place for most of the group's history. Members of the organization joined protestors demanding bread, freedom, and social justice like everyone else, my participant added. Writing on the Muslim Brotherhood's participation in the 2011 Egyptian uprising and their political missteps after the uprising, Eid Mohamed and Bessma Momani (2014: 198) stress that protestors were not protesting in favor of an Islamic government; they were protesting in favor of the people's right to choose.

The frame also created what scholars of social movements term "a movement of movements," as I shall demonstrate in Chapter 5. This is significant, Tilly (1997) contends, for communicating power to opponents. It staged, I suggest, a lineament of diversity. This diversity was significant in showcasing the importance of the voiced demands and their popularity across different sects of society, including women, ${ }^{7}$ an observation confirmed by several individuals interviewed for this book.

The frame also legitimated and energized women's participation in the uprising. This is because to legitimate collective actions, frames, stress Snow and Benford (1992), need to resonate with the population's cultural predisposition. Snow and Benford (1988) define the symbolic resonance of frames as the degree to which a particular frame resonates with cultural norms and familiar concepts. Social movement scholars have analyzed the concept of frame alignment in order to understand the dynamics that contribute to the survival and resonance of contentious language and frames.

Snow and his associates have devoted great attention to examining the process of "frame alignment." Frame analysis describes the ways in which frames are oriented toward action in particular contexts and fashioned at the intersection between a target population's culture and the movement's own norms, strategies, and goals (Tarrow 1998: 110-111; see also Snow and Benford 1992; Snow et al. 2004). They emphasize the

${ }^{6}$ Interviewee 18. Author's interview, Cairo, Egypt, July 2013.

7 Interviewee 4. Interviewee 44. Author's interview, Cairo, Egypt, February 2014. Interviewee 46. Author's interview, Cairo, Egypt, June 2014. Interviewee 68. Author's interview, Cairo, Egypt, November 2014. 
influence of frame alignment on the movement's success. According to them, an unfamiliar frame can alienate people and thus the movement will fail to gain popular support. But also a frame that is nothing more than a reflection of the values of its society will not bring major changes (Tilly and Tarrow 2007: 110; see also Zemlinskaya 2009).

Viewed from this perspective, the absence of gender from women's collective action frame is not a sign of passivity but rather part of the process of "frame alignment." By framing their participation around their "Egyptianness," several participants argue, they were able to negotiate their differences with those opposing their participation from a position of power. " We are all citizens of the same country," a young female protestor explains: "we shared the same responsibilities and duties: the responsibility to defend it [Egypt], and the right to be in the [Tahrir] square."

Some even argued that introducing a gender-explicit frame would have limited women's participation. The absence of gender issues, an activist from Al-Fayoum, a conservative rural town in Egypt, explained was a "blessing in disguise"; ${ }^{10}$ it implicitly extended women's rights - that is, their right to participate in politics and to occupy the public space. ${ }^{11}$ Introducing gender issues even as a demand would risk opening up debates about the proper gender roles and gender risks, "don't you think?" 12 a young female protestor asked me, stressing that this is not necessarily what went through her mind then. The process of frame alignment is not always easy, clear, or uncontested. Scholars note how different groups in a social movement compete among each other, with media agents, and with the state for "cultural supremacy" (Tarrow and Imig 2000: 110).

Frames thus need to be built around strong ties that, Tilly asserts (1997: 133), "do much of the work that would normally fall to organization." Constructing a resonant and modular collective action frame was thus particularly significant for the success of the 2011 uprising given the absence of leadership (Bamyeh 2012; Clarke 2014; Goldstone 2011). The lack of leadership, Momani and Mohamed (2014) explain, was a natural by-product of the nature and direction of the movement.

${ }^{8}$ Interviewee 4. Interviewee 5. Interviewee 2. Author's interview, Cairo, Egypt, July 2012.

9 Interviewee 5.

${ }^{10}$ Interviewee 81. Author's interview, Al-Fayoum, Egypt, November 2014.

${ }^{11}$ Ibid.

12 Interviewee 4. 
The movement's participants, they rightly observe, were more focused on participating in democracy than ideology (Momani and Mohamed 2014: 198). In the absence of ideology, leadership, and organization, a discourse grounded in their rights as citizens and nationals of Egypt offered different participants, including women, a source of framing that easily aligned and resonated with the population's cultural predisposition and communicated a uniform message to the regime in power.

During the interviews, participants often utilized the same language used in describing nationalist and liberation struggles against colonialism, and they similarly described how the uprising was an attempt to "liberate" ${ }^{13}$ Egypt. ${ }^{14}$ Unlike colonialism, their enemy was not Western and/or foreign forces; the enemy they were fighting against was a "local colonist," 15 that is, the corrupt regime of Mubarak. Prior to the uprising, the April 6th movement often mockingly referred to Egypt as the Egyptian Occupied Territories ("Corruption Award [Fassad Award]" 2011). Several protestors described in great detail how the struggle was one aimed at "reclaiming Egypt." 16 They proudly shared how their experience in the uprising revived their sense of ownership, belonging, and loyalty. They contrasted the revived sense of attachment they felt during the uprising with the sense of political apathy that prevailed in the period that preceded it. "I stopped following the news" ${ }^{17}$ was a very common confession made by a number of my female participants, describing their political apathy before the uprising.

In emphasizing this sense of detachment, a couple of my participants cited the popular song "Yaksh Twla" [To Hell with It $]^{18}$ in reference to Egypt. The song, they described, exemplifies the general spirit of political despair among the youth in this time before the uprising. The phrase "To Hell with It" was also commonly posted on Facebook profile pictures and printed on shirts. The song, one participant explains, "[o]ffered a $\operatorname{logo}, " 19$ that is, it captured the anger and resentment that many among the youth were already feeling. This state was fueled by the sense that

${ }^{13}$ Interviewee 56. Author's interview, Cairo, Egypt, October 2014.

14 This national sentiment exists at a level deeper than any particular government and is part of the foundational sentiment in Egypt.

15 Interviewee 70. Author's interview, Cairo, Egypt, November 2014.

16 Interviewee 9.

17 Ibid. And many others who would explain how they stopped following events on the political landscape, and/or refrained from participating in elections.

18 The song is composed and performed by Yasser Al-Manawehly.

19 Interviewee 49. Author's interview, Cairo, Egypt, June 2014. 
the country was lost to the corrupt regime and was held captive by these corrupt forces in power. ${ }^{20}$. Protestors in the 2011 uprising thus attempted to liberate their country, but in this context, the liberation struggle was fought against the internal security forces and the government in power.

The emphasis on national unity ${ }^{21}$ in framing political struggles in Egypt is also part of the broader negative view of identity politics and the lack of support for identity-based demands in Egypt. Civil society organizations, whether secular, liberal, or leftist, have been excessively cautious on issues related to identity politics and gender rights in Egypt. For example, the liberal parties and groups have always avoided offending Islamists and conservative segments of Egyptian society, an activist explained, citing their position in the 2001 Queen Boat controversy in Egypt. ${ }^{22}$ Egyptian human rights activists did not condemn the crackdown and arrest of fifty-two gay men on the charge of debauchery, and their subjection to anal probes following the police raid on the Queen Boat in Cairo (Mourad 2013). According to Amra Shalakany (2007: 9), "the Egyptian human rights community faced a stark choice: Either defending the Queen 52 and risking being painted as supporters of 'sexual deviance' by the viciously homophobic press, or, alternatively, staying clear of the case and risking alienating colleagues from the international human rights community."

The political apathy of Egyptian human rights groups can be attributed to their fear of being labelled agents of the West and/or anti-Islamic (Awwad 2010; Mourad 2013; Shalakany 2007). The liberals' stance could also be the result of the continued relegation of gender, race, and identity politics from the realm of political struggles. As Sara Mourad (2013) argues, their stance also magnifies the undertheorized nature of liberal politics in the Arab world. It points to a need for a more nuanced understanding of the position of liberals and seculars - not just Islamists on issues related to gender rights and sexuality (Mourad 2013).

The unease with which women's rights are viewed and treated at times of struggle is part of the broader skepticism surrounding the "murky

${ }^{20}$ For a general discussion of political alienation, see Finifter 1967; Nachmias 1974. For a discussion of political alienation as a source for political activism, see Thompson and Horton 1960.

21 Egypt is not exceptional in this regard; national metaphors and discourses have been central in historical and modern struggles around the world.

22 Interviewee 42. Author's interview, Cairo, Egypt, February 2014. 
terrain of identity politics," ${ }^{23}$ as several of my participants reminded me, and how "the business of identity politics is unpopular in Egypt" many Arab societies, I would add. One of my interviewees claimed that the majority of the population views identity politics as an "American/ Western thing, really" 25 and, as other participants added, a "colonial strategy" 26 and/or "a foreign conspiracy" 27 aiming to "divide and conquer." ${ }^{28}$ The conventional framing of historical and modern successful political struggles in Egypt was constructed, as already mentioned, around the discourse of national unity, where differences are omitted and the unity of demands and voices is celebrated. In the national imaginary and popular discourse, attaining this national unity has been ingrained as a necessary pre-step for staging a successful political struggle (Badran 1988; Baron and Pursley 2005; Hatem 2000, Pollard 2005).

For example, one of the celebrated symbols of Egypt's struggle against colonialism during the 1920s is the unity between the mosque and the church, described in popular culture and artistic production as the unity between the crescent and the cross, with the crescent symbolizing Muslims and the cross symbolizing Copts in Egypt. Attaining this national unity was viewed as one of the success factors in Egypt's nationalist struggle and as a significant factor in ending colonialism (Al-Faqi 1985; Ebeid 1964; Sedra 2011). Introducing group-based demands, whether by women, religious and/or sexual minorities, would ostensibly put this unified image and consequently the movement at large at risk. ${ }^{29}$

The emphasis on solidarity and the concern to present a unified face to the opposition is among the challenges and constraints of Egyptian

23 Interviewee 4.

24 Interviewee 33.

25 Interviewee 5.

${ }^{26}$ Interviewee 55. Author's interview, Cairo, Egypt, October 2014.

27 Interviewee 62. Author's interview, Cairo, Egypt, October 2014.

${ }_{28}$ Interviewee 30. Author's interview, Cairo, Egypt, July 2013.

29 Interviewees $1,4,5,12,28$. The debate over identity politics in social movements and whether such a focus may often produce movements that are divisive, insular, sectarian, and incapable of garnering support, expanding membership, increasing resonance, and negotiating with allies is common in social movement research (Tarrow 1998: 9; see also Gitlin 1996). This is the criticism that Todd Gitlin makes of contemporary American "identity politics" in his book Twilight of Common Dreams (1996), a weakness that in this case he does not find in class politics of the past. In contrast though, Benedict Anderson ironically asks, contrasting the many monuments to 
society. Women participating in the political struggles in Egypt would more likely reflect them and root themselves within them. In framing their participation, women framed their activism building upon this cultural reservoir to achieve resonance and modularity. This framing proved useful in facilitating their activism, as it concealed gender differences and inequalities that traditionally obscured their activism. This is particularly significant in the case of Egypt, where a gender-explicit approach to equality and women's rights is weak in public debates and often a subject of mockery in media productions.

\section{The Framing of Women's Political Participation in Egypt}

A gender-explicit approach to women's activism - in contentious and/or routine politics - has been less popular in Egyptian society. The gender dimension has often been misrepresented by the media and overlooked in popular accounts. This misrepresentation has contributed to further situating the discourse of women's activism within the framework of national unity. Another implication is that female political activists distanced themselves from feminist discourse and from gender-explicit frameworks. By framing their participation around their citizenship, women mitigated tensions surrounding gender, citizenship, and identity that have long shaped and animated the public discourse around women's political activism.

In Egypt, the media is among the most influential shapers of the Egyptian "self/selves." The media, Egyptian novelist Sonallah Ibrahim (1981) stresses, is central to the everyday lives of citizens, shaping both the individual's private identity and the collective national imagination. ${ }^{30}$ In her study of the media representation of Alia El-Mahdi, an Egyptian female activist known for her controversial nude protest actions, Sara Mourad (2013) argues that the media framing of

nationalism with the lack of memorials to social class, can one even imagine "a Tomb of the Unknown Marxist" (1991: 10). That is, while in the course of history individuals and groups have been prepared to sacrifice their lives for their visions of good society which they represented, nationalism, John Schwarzmantel (2008) explains - elaborating Anderson's contention - has a monopoly on images and constructions of self-sacrifice and heroism in collective memories.

${ }^{30}$ In Ibrahim's 1981 novel Al-Lajna [The Committee], he writes that due to the state's preoccupation with diversification, it also diversified its methods of "persuasion": "these [Arab] regimes used to have a sole method of persuasion, 
women's activism transcends contentious media representations of women to reach into the heart of Egyptian and Arab revolutionary citizenship.

Women's rights organizations are often represented by Egyptian media as "elitist organizations" 31 and/or "aristocratic clubs" 32 ; its members are often misrepresented as "cappuccino ladies," 33 "vicious females," 34 or "masculine women." 35 While there is a myriad of media productions that narrate the bravery of male activists and historical political figures, the stories of female activists and feminists in Egypt have never made it to the mainstream movie and/or television industry. ${ }^{36}$

Several media productions have focused on the life stories of a number of Egyptian female celebrities. In these productions, the characters' nationalist acts are sometimes highlighted - for example, in the media production of the life story of the singer Um Kalthoum and of the actress and belly dancer Tahia Karyuka, to cite only a few. The life stories of Egyptian female political activists and women's rights advocates, however, "have rarely made it to the screen." 37 Their activism, one of my interviewees noted, can be the subject of "a book, not a movie." 38

The absence of female heroines with an explicit gender agenda in media production is situated within the broader misrepresentation of women in Egypt's media (Abu-Lughod 2005; Al-Mahadin 2011; Allam 2004; Qasim and Dasuqi 2000; Sakr 2004, 2007). It is also a manifestation of the "failure and the shallowness [Ikhfaq wa Sațyat]" ${ }^{39}$ of the top-down approach that the ruling regimes in Egypt have adopted in advancing

which was through imprisonment and torture. Diversification, however, put new methods at their disposal that range from assassination to television and parliaments."

31 Interviewee 20. Author's interview, Cairo, Egypt, July 2013.

32 Interviewee 33.

33 Author's interview, Maya Morsy, former Regional Gender Practice Team Leader at the United Nations Development Program/Middle East Office (2014-2015), and current President of the National Council for Women, Cairo, Egypt, October 2014.

34 Interviewee 38.

35 Interviewee 4.

${ }^{36}$ I am unaware of any literature examining the media representation of the women's movement in Egypt, and thus I relied on my participants' insights and my knowledge and exposure to Egyptian media.

37 Interviewee 16. Author's interview, Cairo, Egypt, July 2012.

${ }^{38}$ Interviewee 23.

39 Interviewee 40. Author's interview, Cairo, Egypt, February 2014. 
women's rights. While the policies of state feminism in Egypt have produced a number of women-friendly policies and legislations, they did not alter the way in which society viewed and treated women, as reflected in the media portrayal of them (Hatem 2005; Sholkamy 2012). In an interview with Nahla Abdel-Tawab, regional director of the Population Council ${ }^{40}$ in Egypt, Abdel-Tawab explained how achieving gender equality and women's rights requires not only a formal and technical shift in our policies and processes but also a social and normative shift in Egyptian society. To challenge and change gendered power relations, there need to be change and development in gender relationships and social structures in the family, at work, and at the state level.

Female heroines in political struggles are, however, positively depicted by the media when their activism is framed across nationalist lines. The discourse of women's right to political participation, one protestor stressed, is often celebrated and supported when it is introduced "subtly (Makhfya) ... within the larger discourse of social equality." ${ }^{41}$ Women's activism, another protestor confirmed, is most "gracefully" portrayed when it is a "subheading ('nwan Far'y)" under nationalism. ${ }^{42}$ The significance of this alignment between gender and social equality frames as well as women's political activism and nationalism is further explicated in the following conversation with a media analyst at the Cairo office of an international broadcasting corporation: ${ }^{43}$

RESPONDENT: The image of the muscled feminist is not particularly appealing in Egyptian society.

INTERVIEWER: Hmmm ...

40 The Population Council is an international, nonprofit, non-governmental organization. The council conducts biomedical, social science, and public health research in developing countries. Headquartered in New York, the Population Council has 18 offices in Africa, Asia, and Latin America and carries out research in more than 60 countries. The council's office in Egypt has conducted extensive research on youth and women issues. It has published extensive national surveys of young people in Egypt in 1997, 2003 and in the wake of the 2011 uprising. The Egypt office also manages the International Network to Analyze, Communicate, and Transform the Campaign Against FGM/C (INTACT) to advance research on female genital mutilation (FGM) and facilitate the dissemination and use of research findings.

${ }^{41}$ Interviewee 43. Author's interview, Cairo, Egypt, February 2014.

${ }^{42}$ Interviewee 45. Author's interview, Cairo, Egypt, February 2014.

${ }^{43}$ Interviewee 29. Author's interview, Cairo, Egypt, July 2013. 
RESPONDENT: You look quite skeptical.

INTERVIEWER: Not really. Just thinking it through.

RESPONDENT: Consider how the television series Zaat is quite a success in Egypt these days. While gender equality and women's activism is one of its underlying themes and objectives, the author intelligently weaved it under the broader frame of social equality and national struggle. They sugarcoated it, you can say.

INTERVIEWER: Well Zaat was written in 1992, is this...

RESPONDENT: But it was only produced as a television series in 2013, after the uprising.

INTERVIEWER: Yes, but is this still the case, that women's rights and activism need to be concealed under the master frame of social equality and nationalism to gain support, even after the uprising.

RESPONDENT: Yes, I believe this was the case at the time of the uprising and remains the case after the uprising.

At the time of the interview in 2013, the television series A Girl Named Zaat was being aired in Egypt during the month of Ramadan. The Ramadan series is based on the novel Zaat, published in Cairo in 1992. In 1993, Zaat was nominated as the most important novel of the year. State institutions, however, did not endorse the decision. A decade later, the novel was awarded Egypt's most prestigious literary award, yet Sonallah Ibrahim, the author, declined the "honor" (Haist 2010). Notwithstanding the high number of Ramadan series, Zaat scored the highest rating during that month (Awad 2013).

Zaat is the name of the novel's heroine, an allusion to the medieval Arab folk epic of the warrior princess Zaat al-Himma ("the lady of noble intentions"), who performed heroic acts in the Arab-Byzantine wars of the eighth and ninth centuries. The word Zaat also means "self" in Arabic. The novel is a modern epic in which Zaat, a typical member of the urban middle class, struggles against the adversities of everyday life. The plot starts in the 1960s, as Zaat is forced by her husband to discontinue her studies and become a housewife and the mother of two daughters and later a son. As the 1970s begin and the cost of living increases, she starts working at a newspaper, in the department of proofreading and copy-editing - a euphemism for censorship in Egypt's print media (Haist 2010). Through her job, Zaat is exposed to the malaise of political life and becomes politicized. Her personality stands in contrast 
to her apolitical female colleagues who often critique Zaat's leftist leanings and are preoccupied only with the challenges of everyday life as mothers and wives. In the novel, Zaat is transferred to the archive as a punishment for her ideas and for being a sympathizer of the former leftist president Gamal Abdel Nasser as well as for displaying antipathy toward Egypt's liberal president, Anwar Al Sadat.

Throughout the novel, Zaat performs acts of resistance and demonstrates resilience in her work and at home. She vainly tries to mobilize her neighbors to clean the neighborhood. She decides to practice her rights and responsibilities as a citizen and report a can of olives tagged with a false use-before date to the police and health authorities. Supported by her friend Himma, meaning "the will" in Arabic, she enters a bureaucratic nightmare as she tries to submit an official complaint. For all her efforts, Zaat makes hardly any impression on the worsening living conditions, the decay of public morals, the collapse of state institutions and agencies, and society's drift toward religious fanaticism and political conservatism (Haist 2010; JohnsonDavies 2006).

Mainstream interpretations of Zaat do not assign a gender fault line to the novel. Critiques have interpreted Zaat as a social commentary that provides keen insights into how Egypt has come to be the way it is today (Haist 2010; Johnson-Davies 2006). Zaat's daily struggles, life experiences and social relationships are juxtaposed with economic crises and social changes in Egyptian society. The novel highlights the ubiquitous corruption in society and state institutions, financial scandals, foreign debts, gender inequalities, and human rights violations. Her story is illustrated with extracts from newspapers - headlines, articles, captions, death notices, advertisements - narrating events in broader society as well (Johnson-Davies 2006).

It is impossible to confirm with certainty that women's rights is the animating theme of Ibrahim's novel. It is possible that the central figure in the novel, Zaat, represents Egypt, the nation. Indeed, the representation of Egypt as a woman is a common cultural image, as noted in Chapter 1. It emerged following women's participation in the 1919 uprising and flowered during the Nasserist regime. Zaat's author, Ibrahim, is known as a strong sympathizer of Nasser's nationalist regime.

Notwithstanding the absence of gender from a mainstream reading of the novel, my interviewee's gender reading of Zaat is, however, 
insightful, especially considering the popularity of the series. The popularity of Zaat suggests that the figure of the active female citizen is celebrated and "gracefully represented" when her activism and struggle are framed within the nationalist discourse. It is hard to imagine Zaat's series gaining the same popularity if the "dosage of gender equality and sexuality was higher," 44 another participant stressed. The televised reproduction of the novel toned down many of Zaat's questions regarding her sexuality and religiosity, although these themes are covered in great detail in the original novel.

Women's bodies and sexuality in the Middle East, and elsewhere, are a much-contested and debated discursive space (Al-Mahadin 2011; Hafez 2014; Mourad 2013). Salam Al-Mahadin (2011: 8) argues that it is the "ultimate signifier' with a multitude of meanings that spill into various aspects of social, political, religious and economic life." In this sense, women and especially their bodies construct and reflect the social order in the Arab world. The status of a woman's body is a reflection of the moral status of the society. Other female characters in a number of television series aired in the same month as Zaat were, unlike Zaat, dressed liberally, had multiple love partners, and viciously ran businesses. I asked my participants why Zaat's agency was carefully displayed, while in other series aired at the same time, female characters were increasingly portrayed as powerful, even if in a misguided way. One of my participants explained that Zaat resembles the average Egyptian women: "you can relate to her in clothes, home, and profession." 45 Her actions and views, thus, "cannot be too liberal or too deviant" she argued, because Zaat is a role model, and role models need to be carefully constructed and represented.

Meanwhile, the liberal female characters in other series are clearly not a representation of the average Egyptian woman; their exceptionality is underscored and stressed in every single detail in the story. "You can thus play with this character," another participant attests; she is not "a potential role model, thus you can assign to her extreme actions, extreme views, an extreme liberal dress code and exceptionally powerful personality even if in a twisted way." Furthermore, the story line of these seemingly powerful women evolves in such a way

44 Interviewee 32. Author's interview, Cairo, Egypt, August 2013.

45 Interviewee 28. 
that the audience ends up pitying some, despising others, but never adopting them as role models. ${ }^{46}$

Seen as such, women's false expression of liberation and agency - in their liberal way of dressing and their multiple sexual relations, all of which clashes with the predominant customs and traditions in Egypt is a reflection of the malaise in Egyptian society rather than a manifestation of the powerful female citizen. Writing on the ideal forms of citizenship, Lisa Rofel (2007) suggests that "Citizenship, or belonging, is not merely a political attribute but also a process in which culture becomes a relevant category of affinity," and adds "Sex is a critical site where normalizations of cultural citizenship are being reformulated" (94-95). Appropriating Rofel's argument, the careful construction of Zaat's female agency and the framing of her activism along nationalist lines can thus be read as an attempt to articulate a certain image for the ideal female citizen. This image is integral to the process of constructing a gendered collective imagination of female heroines and activists.

Given the important role of the media in framing public discourse in Egypt, the media misrepresentation of women's movement in Egypt, I suggest, contributed in part to the framing of women's political activism. Gender-explicit approaches to women's rights and political participation have often been belittled in media productions and public discourse. The life story of feminist activists, as well, "has not made it to the podium of media commemoration." ${ }^{47}$

In mitigating these tensions involved in women's activism and political participation, women have tapped into the legacy of the nationalist discourse in Egypt in framing their participation. This nationalist discourse does not explicitly include gender issues and women's rights in its framing of collective action. Its supremacy in Egypt should also be situated within the unpopularity of identity politics in Egypt and the association of the women's rights movement with the agenda of the regime as well as Western/foreign pressures. It, thus, comes as no surprise that a gender-explicit frame to women's participation did not resonate with female protestors let alone the wider movement. The absence of gender from the framing of women's participation is thus the function of the political and cultural landscape of Egypt.

46 Interviewee 30.

47 Interviewee 45. 
Notwithstanding the impact of this framing on the success of the uprising, this framing, I argue in the following section, had its own implications for limiting women's rights in the post-uprising period.

\section{Women-Only Spaces: Friends of the Square}

As noted, scholars within the tradition of collective action framing argue that an unfamiliar frame can alienate people and thus the movement will fail to gain popular support (Snow and Benford 1992; Snow et al. 2004; Tarrow 1998: 100). A frame that is nothing more than a reflection of the values in its society cannot also bring major changes to it (Tilly and Tarrow 2007: 110; see also Zemlinskaya 2009).

Several social movement scholars have extended this argument to consider how women have fared in the socialist regimes of Latin America in the aftermath of revolutions (Chinchilla 1994; Fisher 1993; Kuumba 2001; Noonan 1995). The influence of women's pretransition frames in constraining and/or facilitating their demands for equality in the new nationalist states soon became the foci of numerous feminist studies in the 1980s and 1990s. Within this tradition, scholars have observed that women whose pre-transition frame incorporated gender equality achieve more gains under new democratic regimes (Jaquette 1973; Kampwirth 2002; Noonan 1995; Reif 1986).

Pre-transition frames can also constrain the success of later movements and limit women's rights. In Latin America, female protestors appropriated the authoritarian regimes' discourse of the pious woman and selfless mother in framing their political participation and struggle for democratic reform (Alvarez 1999; Okeke-Ihejirika and Franceschet 2002; Ray and Korteweg 1999). This framing, however, constrained women's activism in the period following the uprisings. New political actors used women's feminine framing to justify women's exclusion from the public space and to encourage female activists to return to the private sphere (Chinchilla 1994; Fisher 1993).

Within these studies, feminists have also observed that women achieve more gains if their collective action frames are accepted by broader society and also aligned with feminist demands (Alvarez 1999; Chinchilla 1994; Fisher 1993; Noonan 1995). The incorporation of gender in women's collective action frame benefited their organizations and in some cases produced strong women's movements in post-transition periods (Adams 2002; Baldez 2002; Molyneux 1985; 
Noonan 1995). This is because women-only spaces - also dubbed women's free spaces (Evans 1986) and prefigurative groups (Polletta 1997) - are tolerated in movements that incorporate gender into their frames more than the ones that gloss it under nationalist or liberation discourses.

The presence of "conceptual" and "social" women-only spaces in ongoing movements, Sara Evans and Harry C. Boyte (1986) stressed in explaining Evans' then nascent term, is important to challenge gender inequalities. Other scholars also note the importance of these spaces in prefiguring "the society the movement is seeking to build" (Evans and Boyte 1986; Polletta 1997: 11; Taylor 1989). Evans and Boyte (1986: 102) attest that the presence of "women-only spaces" in the Southern civil rights movement gave rise to radical feminism in the USA in the 1970s. They explain how: "within the broader social space of the movement, women found a specifically female social space in which to discuss their experiences, share insights, and group strength as they worked in the office or met on the margins of big meetings" (Evans and Boyte 1986: 102; see also Allen 1970).

It is important to note that women's spaces in ongoing movements are not necessarily feminist spaces - in the Western liberal sense, that is, women do not necessarily join them to achieve gender equality. The narrative of individual and collective liberty, postcolonial feminists hold, does not exhaust the desires of women in these spaces (Abu-Lughod 1990; Ahmed 2012; Mahmood 2005; Nouraie-Simone 2005). These spaces are what their members make of them; they do not necessarily include discussions of gender issues and women's rights demands.

For instance, women's spaces within a revolutionary movement could differ between urban and rural sites. This is in part because women's oppression, several feminists note, is multicausal and mediated through a variety of different structures, mechanisms, and levels which may vary considerably across space and time (Mahmood 2005; Molyneux 1985; Nouraie-Simone 2005). I do not intend to tease out these differences in my study; rather, I argue that the absence of conceptual women-only spaces at the time of the Egyptian uprising contributed, in part, to limiting their rights.

This is because, in social movements, women's spaces offer women a safe haven to articulate greater consciousness of what makes them marginal and garner greater confidence in their ability 
(Evans 1980, 1997; Gamson 1975; Polletta 1997). In her study of women-only spaces in the Southern civil rights movement, Francisca Polletta (1997) describes how in these spaces, women, feminist organizations, NGOs, unions, and political parties articulate gender concerns and build gender-awareness groups that eventually turn into a women's movement. In the context of the 2011 Egyptian uprising, participants argue that while there have been "physical" women-only spaces for female participants, gender issues were not discussed in these spaces. As such, there was no real "conceptual space" to garner gender-based coalitions and awareness.

In the case of Egypt, the young female participants, Ghada Lotfy director at the Egyptian Center for Women's Rights - attests, "did not want to disrupt the unity" 48 that characterized the uprising. In fact, for quite some time following the uprising there has been a "juncture between the old generations of women's rights groups in Egypt and young female activists," ${ }^{49}$ to use the words of Maya Morsy, former regional gender practice team leader at the United Nations Development Program/Middle East Office (UNDP) and current president of the National Council for Women in Egypt. Many of the young activists, Maya explained, have sadly "ignored our calls for unity (Itihad)" during the uprising. ${ }^{50}$ It is worth noting, though, that this juncture did not last long, a fact that Azza Soliman - founder of the Center for Egyptian Women's Legal Assistance (CEWLA) - emphasized to me. ${ }^{51}$ This is evident as well in the number of women's rights groups and initiatives carried out by young activists and the collaborative projects put forward by older and newer waves of women's rights advocates in Egypt.

Charles Tilly (1975) concludes from his study of contention in Europe that it was not mobilization that produced reform. Reform was rather the result of realignments among the new political actors and the coalitions in power. It was triggered by mobilization and harnessed by skillful political players (1975: 184). In so doing, Tilly explains much of the variance in the outcomes of contention by intervening causal mechanisms rather than independent ones. In the

48 Author's interview, Ghada Lotfy, director at the Egyptian Center for Women's Rights (ECW), Cairo, Egypt, July 2013.

49 Author's interview, Maya Morsy.

50 Ibid.

51 Author's interview, Azza Soliman, founder of the Center for Egyptian Women's Legal Assistance (CEWLA), Cairo, Egypt, November 2014. 
context of Blacks and Hispanics struggling for equality in American urban centers, Browning and his collaborators argue that participation in protest was not sufficient to introduce reforms and advancement in the status of minority groups (Browning, Marshal, and Tabb 1984). Reforms were the result of a widening in the political opportunity structure, mobilization, elections, and political realignments (Browning et al. 1984).

Sidney Tarrow and his collaborators, in a similar vein, argue that political change occurred not through protests or clashes between old and new paradigms in Western Europe and North America during the 1960s and 1970s (Tarrow 2012: 186; see also Tarrow 1993, 1996; McAdam et al. 2001) but through the competition between parties, unions, interest groups, and movements, through reform, and through the absorption of at least a proportion of the protestors into the party system after mobilization ended.

I do not suggest that since the absence of gender from women's collective action frame limits the effectiveness of women-only spaces, then gender inequality will inevitably follow contention. As I have already argued, the non-immediate and mediated outcome of participation in contention is significant regardless of the success or failure of the cycle of protest. Through their participation in these episodes, new female activists are trained and develop a repertoire of actions. These activists could then form new movements and might engage with parties and interest groups after the episode of contention is over. The significance of the women-only spaces is that in these spaces, conceptually, women sketch themes that the new movements would incorporate and coordinate. Their absence delays rather than obscures reform.

My analysis of women-only spaces is intended to highlight how the revolutionary moment might have contributed to the current gender order in Egypt. Thus, I do not claim to offer an exhaustive explanation for gender inequality in Egypt following the uprising. I argue that the absence of conceptual women-only spaces, notwithstanding their physical presence, limited women's rights but did not erode their activism in the post-uprising period. This analysis is significant as it not only complements but also better completes the discussion of women's collective action frame in the Egyptian uprising. Any discussion of women's framing of their participation would be incomplete without thinking about - or at least imagining - the implications of this framing on their rights and activism in the period after the 
uprising. Despite the limitations of my analysis, this analytical model can be explored across additional cases and in combination with other factors. The analysis is also meant to encourage future research on the meaning and significance of the growth in women's activism following the uprising.

\section{Conclusion}

I have just always felt that the national unity talk is sometimes real but also and for sure partly orchestrated, particularly at times of contentions and political struggles. 52

This chapter opened up with the aforementioned statement, as it captures the dynamics that shaped women's collective action frame in the 2011 uprising. While the comment was made in the context of Copts' engagement in political struggles in Egypt, it can be applied to the different groups in Egyptian society. In the case of women, adopting the citizen frame was, I suggest, in part a strategic response by women to the supremacy of the historical national discourse in Egypt - a discourse that has traditionally emphasized the importance of national unity in staging political struggles and in communicating power to opponents. This framing facilitated their participation at the time of the uprising, but it also, arguably, limited their rights in the period after the uprising.

As I demonstrate, the nationalist discourse has framed Egypt's historical political struggles and women's political activism in the national collective memory and in popular accounts - as documented by the media and popular representations of these struggles. In contrast, a gender-explicit approach to women's activism and rights has often been the subject of critique and belittling in Egyptian society. Several female activists and women's rights organizations, I observe, have thus distanced themselves from an explicitly feminist label. In the absence of an alternative strong discourse for women's activism, the nationalist discourse represented one of the important cultural reservoirs that activists reflected on in the framing of their participation. This framing was modular and resonated with the cultural predisposition of Egyptian society. It thus dignified and energized collective action and

52 Interviewee 31 . Italics mine. 
mobilization among women as well as other participants in the 2011 uprising.

My analysis suggests that the absence of gender secured women's participation in the uprising yet contributed to limiting their rights after the uprising. Espousing a political process approach, I argue that female protestors oriented their messages in relation to the existent opportunities and constraints. This framing temporally concealed differences and inequalities that had traditionally obscured women's participation in politics. However, from a feminist perspective, the absence of women-centered demands implies the absence of conceptual spaces for women. In these spaces, feminist organizations, unions, and political parties articulate gender concerns, and also build networks and gender-awareness groups that could eventually turn into a broader women's movement.

By offering a gender analysis of these early interactions, I attempt to advance an explanation of the nature and implications of their gender dynamics. The resulting analysis is temporally and spatially bounded. However, my focus on identifying the frame's limits and opportunities when analyzing it can be extended to other cases.

The significance of my approach to women's collective frame is that it reclaims women's agency and situates women's participation within the contentious and conventional politics in Egypt. Female protestors operated on the boundaries of constituted politics, embedded power relations, and established institutions. They are, in this sense, "strangers at the gates" (Tarrow 2012), demanding changes and reform but also accommodating inherited understandings and ways of doing things. Their repertoires and collective action frames are best read in light of their relation to conventional and contentious political discourses in Egypt. 